Document downloaded from:

http://hdl.handle.net/10251/81746

This paper must be cited as:

Borsa, MB.; Jungblut, R.; Pérez-Herranz, V.; Müller, L.; Moura Bernardes, A.; Bergmann, C. (2016). Electrochemical treatment of a graphitic forging lubricant effluent: The effect of chloride concentration and current density. Separation Science and Technology. 51(1):126134. doi:10.1080/01496395.2015.1086799.

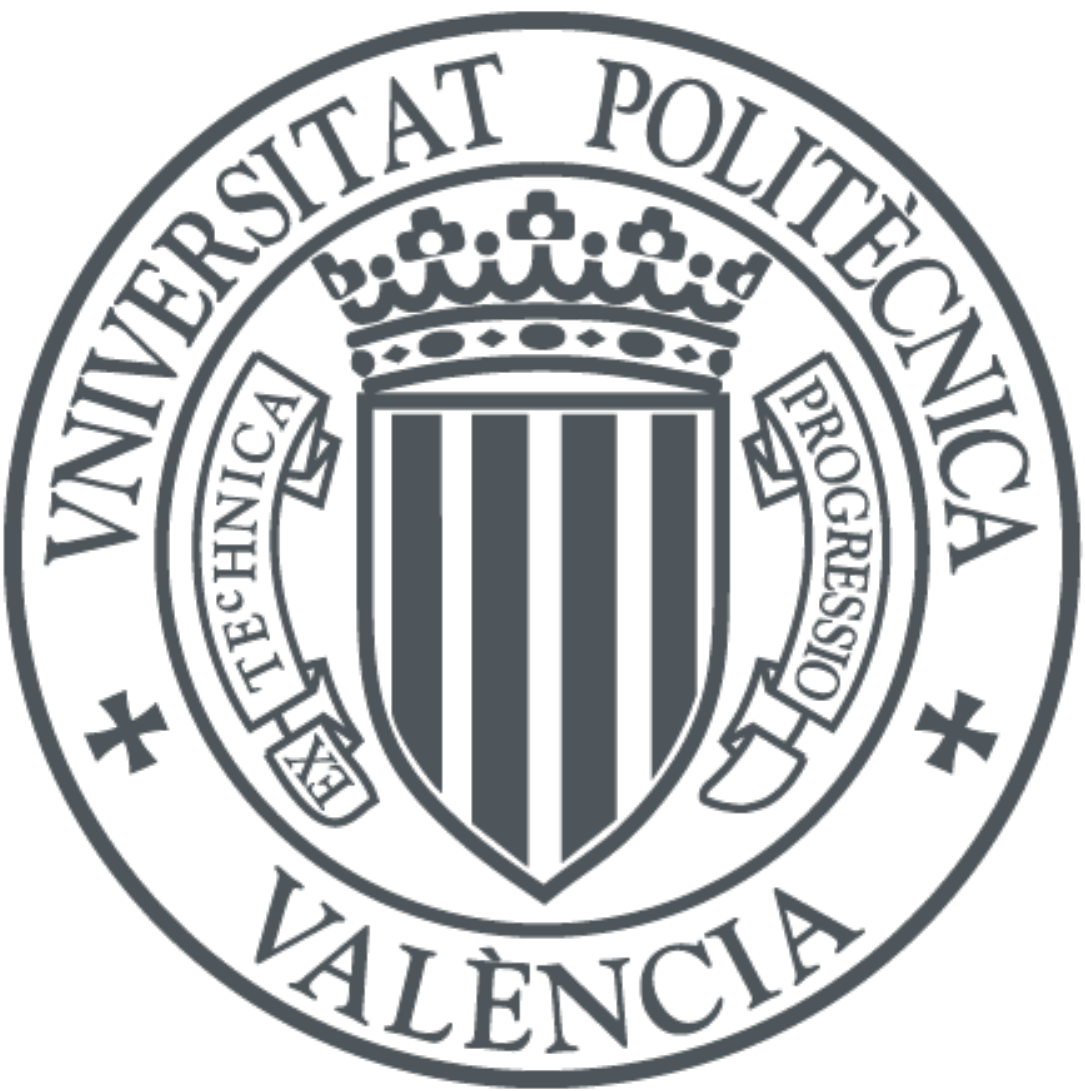

The final publication is available at

http://doi.org/10.1080/01496395.2015.1086799

Copyright Taylor \& Francis

Additional Information 


\title{
Electrochemical treatment of a graphitic forging lubricant effluent: The effect of chloride concentration and current density
}

Maria Beatriz Borsa ${ }^{\mathrm{a}, \mathrm{b}}$, Ricardo Jungblut ${ }^{\mathrm{a}}$, Valentín Pérez-Herranz ${ }^{c}$, Iduvirges Lourdes Müller ${ }^{\mathrm{a}}$, Andrea Moura Bernardes ${ }^{a}$, and Carlos Pérez Bergmann ${ }^{a}$

aPPGE3M - Universidade Federal do Rio Grande do Sul, Porto Alegre, RS, Brazil;

${ }^{\mathrm{b}} \mathrm{GKN}$ Driveline Brazil, Porto Alegre, RS, Brazil;

${ }^{c}$ Departamento de Ingeniería Química y Nuclear - Universitat Politècnica de València, València, Spain

\begin{abstract}
The graphite removal and the chemical oxygen demand (COD) reduction by the electrochemical treatment of an effluent containing a lubricant (oil in water emulsion with graphite) was investigated. The electrochemical cell used a pair of aluminum plates. Since the effluent conductivity was very low, $\mathrm{NaCl}$ was used as supporting electrolyte and different current densities as well as different distance between the electrodes were applied. In lower current densities, higher chloride concentrations implied in smaller COD values. The same behavior was observed when electrode distance was decreased. All the tested conditions presented significant graphite removal and COD reductions larger than $94 \%$.
\end{abstract}

\section{KEYWORDS}

Electrocoagulation; aluminum; COD; graphite; graphitic forging lubricant effluent 


\section{Introduction}

Electrochemical techniques are used as an alternative to conventional wastewater treatments. In these treatments, metal plates are used as electrodes in order to provide the solution with metallic ions that will act as coagulants like the inorganic salts in traditional physical-chemical treatments. When aluminum is used as a sacrificial anode, the polynuclear formation of hydroxylaluminum particles is a stepwise process, involving a deprotonation-dehydratation mechanism. The hydrogen evolution in the cathode, besides raising the solution $\mathrm{pH}$, which leads to hydrolysis and condensation of $\mathrm{Al}(\mathrm{H} 2 \mathrm{O})_{6}^{3-}(1)$, will also help in the flotation of the pollutants present in the effluent. The anodic and cathodic reactions involved in this mechanism are the following:

$$
\text { Anodic: } A l_{(s)} \rightarrow A l_{(a q)}^{3+}+3 e^{-}
$$

$$
\text { Cathodic: } \begin{aligned}
2 \mathrm{H}_{2} \mathrm{O}_{(l)}+2 e^{-} \rightarrow \mathrm{H}_{2}+2 \mathrm{OH}_{(\mathrm{aq})}^{-}(\text {in neutral or alkaline medium) } \\
2 \mathrm{H}^{+}+2 e^{-} \rightarrow \mathrm{H}_{2} \text { (in acidic medium) }
\end{aligned}
$$

According to several authors (2-9), current density is a key parameter in an electrochemical assisted process and affects not only the system's response, but also the dominant mode of separation. Another significant para- meter is the effluent conductivity, since it determines cell resistance and may affect process efficiency. Hence, it is common to add a supporting electrolyte to decrease energy consumption. One of the most common salts used is $\mathrm{NaCl}$ because of its versatility $(9,21)$. They can also promote pitting corrosion in the electrodes, which can lead to an increase in current efficiency.

Electrocoagulation has been studied for the treatment of different effluents as the ones from papermill processes (8), the ones containing $\mathrm{Cr}^{6+}(10,11,18,19,22)$, dairy waste-waters (13), textile effluents (15), wastewaters containing dyes $(17,23,24)$, and others $(16,20,25,26)$. Oil-in-water emulsions were also treated by electrocoagulation/electro-flotation processes by different authors $(4,6,12,14,27-30)$. Nevertheless, the treatment of an effluent from forging operations to simultaneously break the oil in water emulsion and remove the graphite from the wastewater through electrocoagulation is still a matter of research.

The objective of the present study is to evaluate the influence of chloride concentration and current density on the graphite separation and on the reduction of COD in the effluent from a mechanical process lubricant. A patent was requested for the application of this process in Brazil under the registration number BR 102013 028236-7 on November 1, 2013. 


\section{Experimental}

The effluent used in this study came from a warm forging operation at GKN Driveline Brazil, which uses a graphitic lubricant (an oil-in-water emulsion with graphite) with high stability to sedimentation. The effluent also includes water, iron scales, and mineral oil. The effluent characteristics are shown in Table 1.

Table 1. Effluent characteristics.

\begin{tabular}{ll}
\hline Parameter & \multicolumn{1}{c}{ Result } \\
\hline Biochemical Oxygen Demand (BOD) & $79.337 \mathrm{~g} \cdot \mathrm{L}^{-1}$ \\
Chemical Oxygen Demand (COD) & $238 \mathrm{~g} \cdot \mathrm{L}^{-1}$ \\
Mineral Oil and Greases & $287 \mathrm{~g} \cdot \mathrm{L}^{-1}$ \\
Suspended Solids & $35.4 \mathrm{~g} \cdot \mathrm{L}^{-1}$ \\
$\mathrm{pH}$ & 8.0 \\
\hline
\end{tabular}

Figure 1 presents the flowchart of experimental steps carried out at this work.

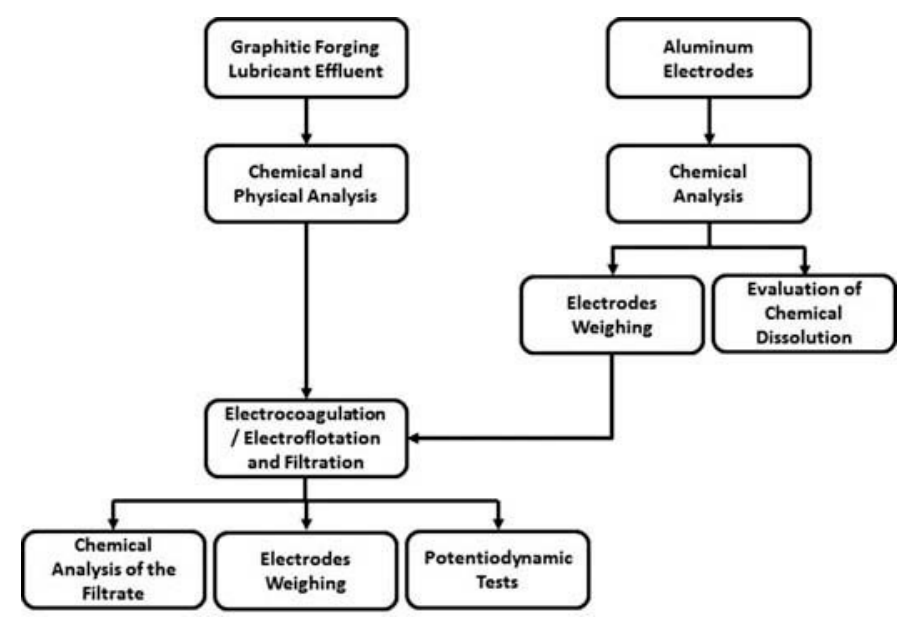

Figure 1. Flowchart of the experiments.

The particle size of the graphitic lubricant effluent was analyzed by laser diffraction, on a CILAS Particle Size Analyzer model 1180.

The electrochemical experiments (electrocoagulation/electroflotation) were carried out using a $2 \mathrm{~L}$ Beaker cup as the reactor, an Icel PS-5000 as power source for continuous current supply and a magnetic stirrer to maintain stirring at $150 \mathrm{rpm}$. Each experiment used 1 liter of effluent, avoiding the leaking of the resultant floated material. All parameters in the effluent were evaluated prior the treatment. After the electrochemical treatment and gravity filtration, the 
obtained filtrate was also chemically analyzed. The filtration was carried out using an $8 \mu \mathrm{m}$ paper filter. Figure 2 shows a schematic representation of the reactor's assembly.

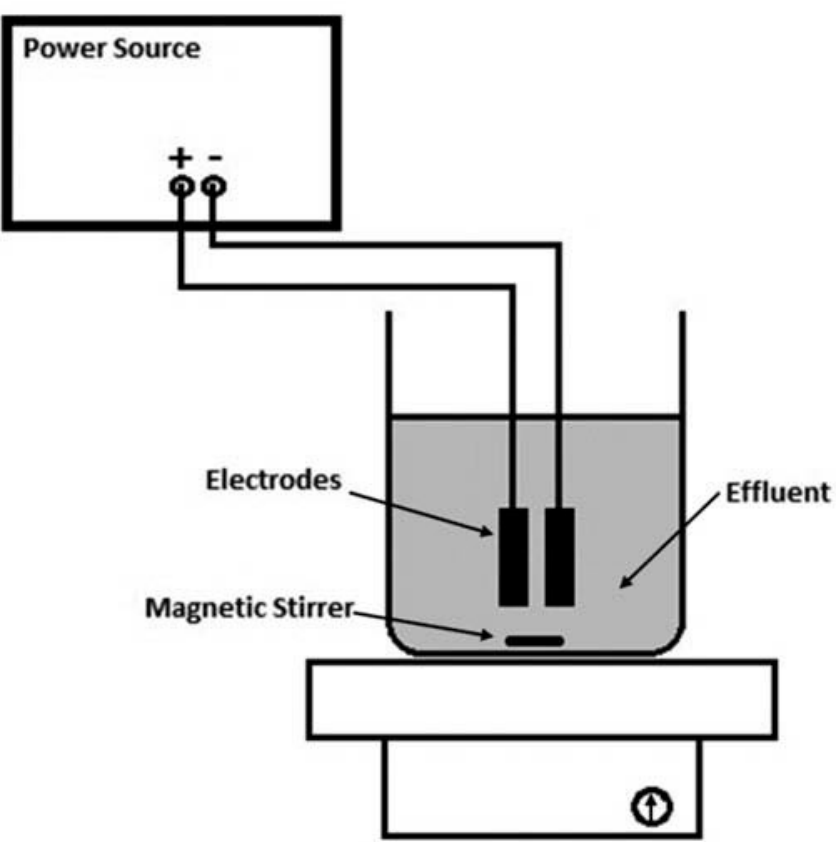

Figure 2. Schematic design of the experiment.

Pairs of $40 \mathrm{~mm} \times 80 \mathrm{~mm}$ commercial aluminum electro- des were used to run the tests. The chemical composition of the electrodes is given on Table 2.

Table 2. Aluminum chemical composition.

\begin{tabular}{lccccccc}
\hline $\mathrm{Al}$ & $\mathrm{Mg}$ & $\mathrm{Fe}$ & $\mathrm{Cu}$ & $\mathrm{Mg}$ & $\mathrm{Si}$ & $\mathrm{Ti}$ & $\mathrm{Zn}$ \\
\hline 99.14 & 0.66 & 0.18 & 0.06 & 0.06 & 0.05 & 0.019 & 0.01 \\
\hline
\end{tabular}

The applied current densities were $0.047{\mathrm{~A} . \mathrm{cm}^{-2}}^{-2} 0.094 \mathrm{~A} \mathrm{~cm}^{-2}$, and $0.188 \mathrm{~A} \mathrm{~cm}^{-2}$ according to the experiments from Arslan-Alaton et al. (23). The distances between electrodes were 10 $\mathrm{mm}, 20 \mathrm{~mm}$, and $40 \mathrm{~mm}$, aligned with Sanchez-Calvo et al. (27). The supporting electrolyte used was $\mathrm{NaCl}$ and the following concentrations were used: $1 \mathrm{~g} \mathrm{~L}^{-1}, 2 \mathrm{~g} \mathrm{~L}^{-1}, 4 \mathrm{~g} \mathrm{~L}^{-1}, 8 \mathrm{~g} \mathrm{~L}^{-1}$, and $10 \mathrm{~g}$ $\mathrm{L}^{-1}$.

To evaluate the chemical attack of aluminum by chloride, aluminum plates were weighed and dipped on different $\mathrm{NaCl}$ solutions for 24 hours. After this dipping procedure, the plate's weight was measured again to determine weight loss. 
The chemical oxygen demand (COD) of the filtrate obtained after the treatment was analyzed through the colorimetric method using a PG Instruments T80+ UV/VIS Spectrometer.

In order to better understand the electrochemical behavior of the system, potentiodynamic curves were accomplished with solutions with different chloride concentrations. The tests were carried out using an Autolab PGSTAT 302 potentiostat with the aid of the software GPES and a scan rate of $0.02 \mathrm{~V} / \mathrm{s}$. In potentiodynamic tests, the reference electrode was saturated calomel, the counter electrode was platinum, and the electrolyte was the effluent. 


\section{Results and discussion}

The effluent is mainly a very stable emulsion with a fine particle size, which can be seen in Table 3. This fine particle size helps in the emulsion stability.

Table 3. Particle size distribution.

\begin{tabular}{ll}
\hline Diameter at $10 \%$ & $2.65 \mu \mathrm{m}$ \\
Diameter at $50 \%$ & $12.50 \mu \mathrm{m}$ \\
Diameter at $90 \%$ & $27.91 \mu \mathrm{m}$ \\
Mean Diameter & $14.17 \mu \mathrm{m}$ \\
\hline
\end{tabular}

Figure 3 shows the physical aspect of the effluent (a) before the electrochemical treatment, (b) after the electrochemical treatment, and (c) after the filtration. It is possible to observe that the graphite was separated from the emulsion.

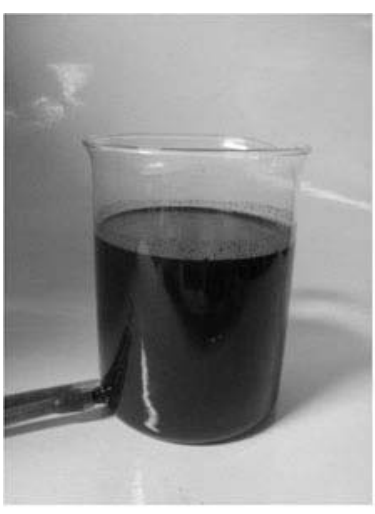

(a)

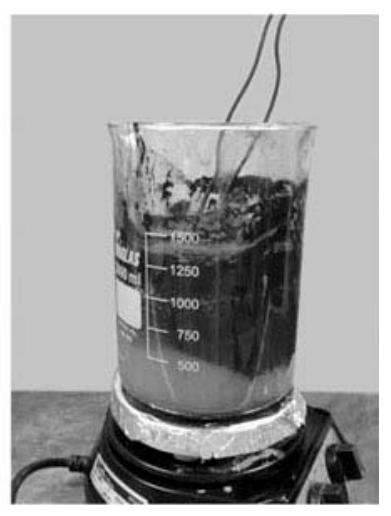

(b)

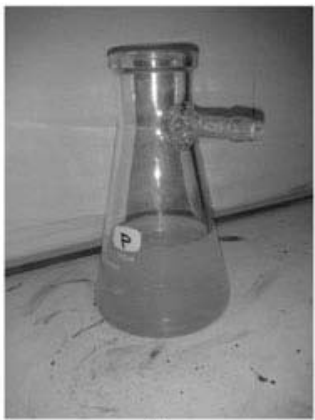

(c)

Figure 3. Physical aspect of the effluent (a) before and (b) after the electrochemical treatment and (c) after filtration.

Although $\mathrm{pH}$ is normally a very important parameter in electrocoagulation/electroflotation, it was decided not to vary the initial $\mathrm{pH}$, once the object of the study was a real industrial effluent. The final $\mathrm{pH}$ value (after the treatment was finished and the effluent filtrated) was reduced from 8.0 to values between 5.0 and 6.0 in all tests that were carried out, independently of the applied parameters (chloride concentration, distance between electrodes and current density) as it can 
be seen in Figures (4a-4c).

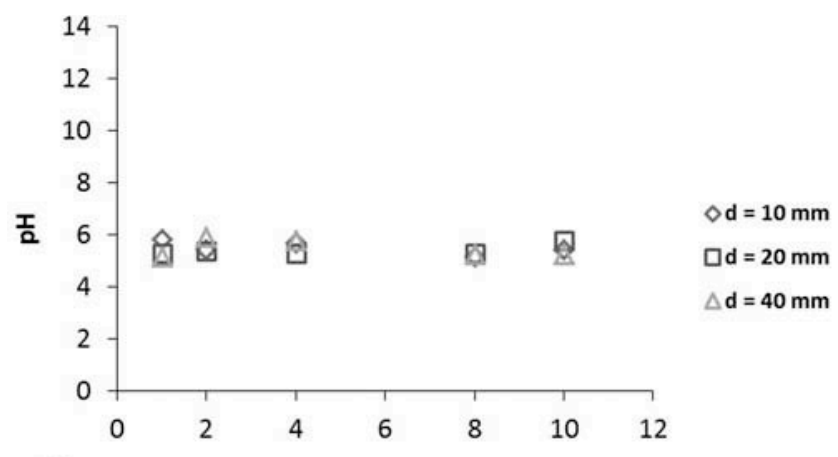

(a) Chloride Concentration (g. $\left.\mathrm{L}^{-1}\right)$
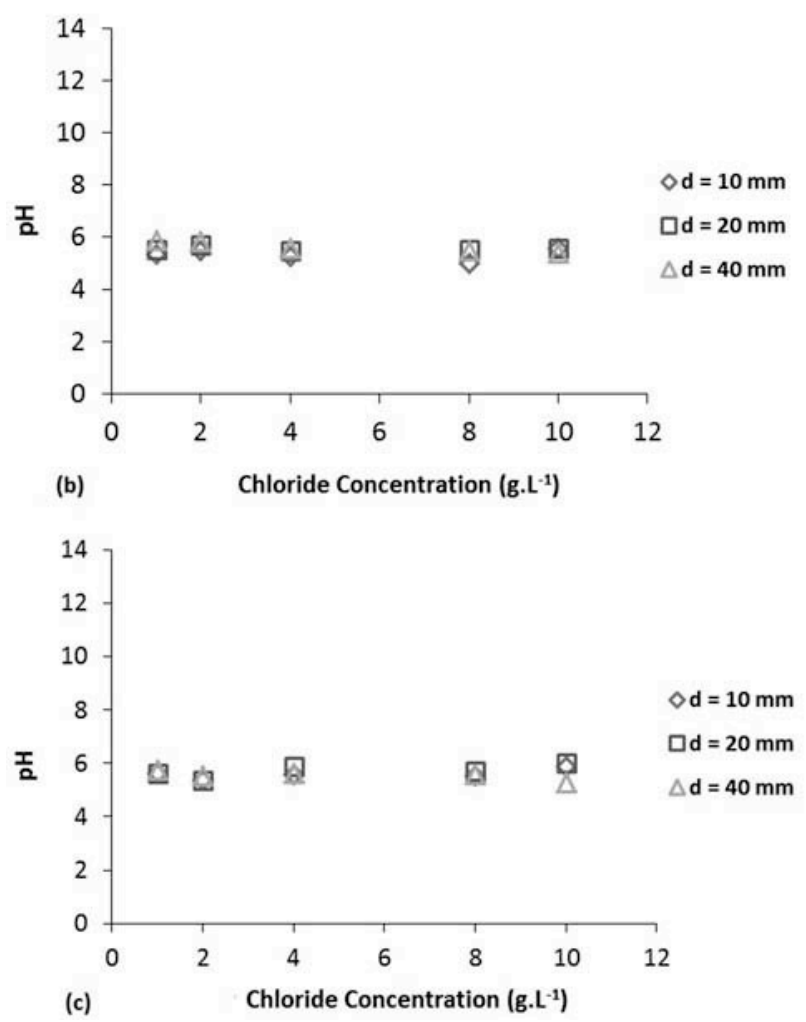

Figure 4. $\mathrm{pH}$ values as a function of chloride concentration after the treatment with different electrodes distances and current densities (a) $\mathrm{J}=0.188 \mathrm{~mA} \mathrm{~cm}^{-2}$ (b) $\mathrm{J}=0.094 \mathrm{~mA}$ $\mathrm{cm}^{-2}$ (c) $\mathrm{J}=0.047 \mathrm{~mA} \mathrm{~cm}^{-2}$.

\section{Effect of current density}

According to Fig. 5, for a chloride concentration of $4 \mathrm{~g} \mathrm{~L}^{-1}$ and $\mathrm{d}=10 \mathrm{~mm}$ the COD reduction was very high and practically constant in the three current densities tested $(\mathrm{J}=0.047 ; 0.094$ and $0.188 \mathrm{~A} \mathrm{~cm}^{-2}$ ), obtaining reductions of $94.08 \%, 94.09 \%$, and $94.31 \%$, respectively. When the chloride concentration was $8 \mathrm{~g} \mathrm{~L}^{-1}$, a similar behavior was observed as the current density increased in the system. 


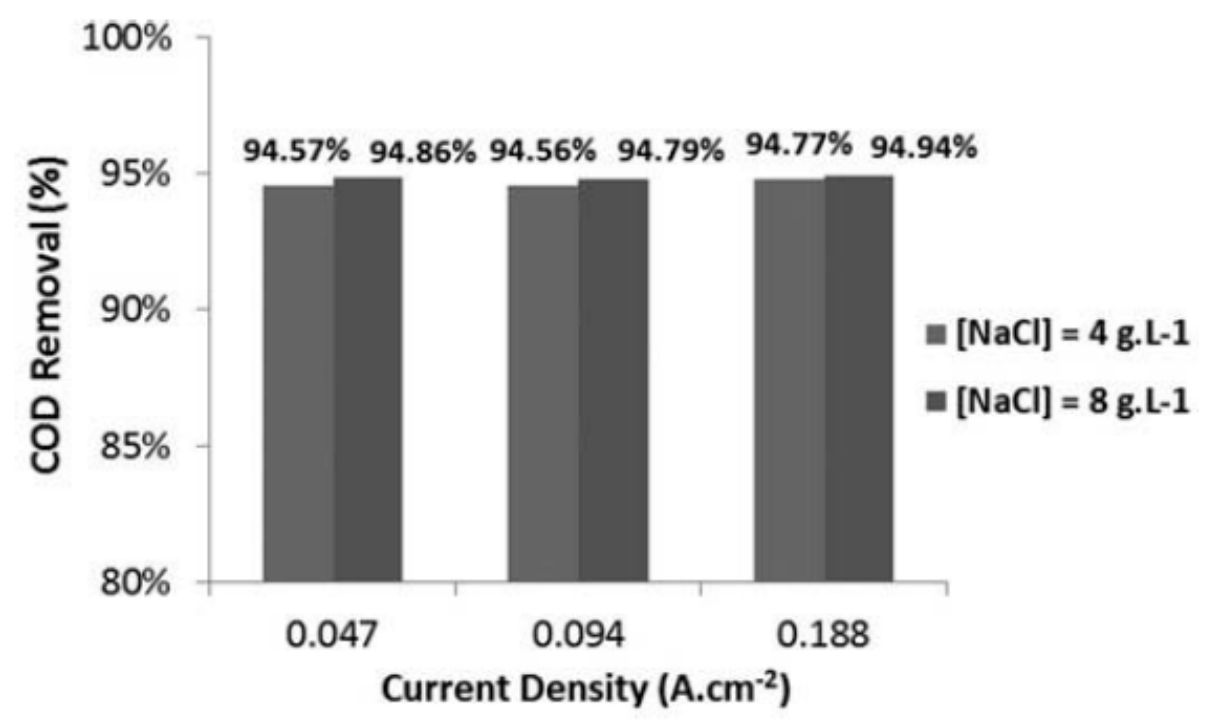

Figure 5. Current density effects on COD removal. $d=10 \mathrm{~mm} ;(\mathrm{NaCl})=4$ and $8 \mathrm{~g} \mathrm{~L}^{-1}$.

According to Faraday's Law, the higher the current density, the greater the aluminum dissolution, which is confirmed by the data presented in Table 4.

Table 4. Theoretical and measured aluminum quantities for different current densities and $\mathrm{NaCl}$ concentrations.

\begin{tabular}{|c|c|c|c|c|c|}
\hline \multirow[b]{2}{*}{$\begin{array}{l}\mathrm{J}(\mathrm{A} . \\
\left.\mathrm{cm}^{-2}\right)\end{array}$} & \multirow{2}{*}{$\begin{array}{l}\text { Theoretical } \\
\text { dissolved } \\
\text { Al (g) }\end{array}$} & \multicolumn{4}{|c|}{ Dissolved Al (g) } \\
\hline & & $\begin{array}{l}{ }^{a} \mathrm{NaCl}= \\
1 \mathrm{~g} \cdot \mathrm{L}^{-1}\end{array}$ & $\begin{array}{l}{ }^{b} \mathrm{NaCl}= \\
4 \mathrm{~g} \cdot \mathrm{L}^{-1}\end{array}$ & $\begin{array}{l}{ }^{b} \mathrm{NaCl}= \\
8 \mathrm{~g} \cdot \mathrm{L}^{-1}\end{array}$ & $\begin{array}{l}{ }^{a} \mathrm{NaCl}= \\
10 \mathrm{~g} \cdot \mathrm{L}^{-1}\end{array}$ \\
\hline 0.047 & 0.25166 & 0.2617 & 0.2645 & 0.2740 & 0.3009 \\
\hline 0.094 & 0.50333 & 0.5022 & 0.4804 & 0.4858 & 0.5029 \\
\hline 0.188 & 1.00667 & 0.8873 & 0.9053 & 0.9188 & 0.8993 \\
\hline
\end{tabular}

The data in Table 4 also shows that in the lowest current density, more aluminum is dissolved than would be expected by Faraday's Law. These super-Faradaic efficiencies are reported in the literature and they may be explained in terms of chemical dissolution of the anode (4), chemical attack of both anode and cathode, which can occur due to acidity and alkalinity produced in the vicinity of the electrodes (31) and pitting corrosion of the anode, caused by chloride ions (32).

Figure 6 shows the amount of dissolved aluminum when an aluminum plate was dipped into a $\mathrm{NaCl}$ solution for $24 \mathrm{~h}$. One can observe that as the chloride concentration increases, the amount of dissolved aluminum is higher, which is consistent to the literature data that says that the higher the chloride concentration, the higher is the corrosion promoted by $\mathrm{Cl}$ - ions 
over aluminum surface (33-39). It is also possible to notice that the amount of chemically dissolved aluminum is small. From these data, it is possible to notice that the chemical attack has no significant influence over the overall electrodes dissolution.

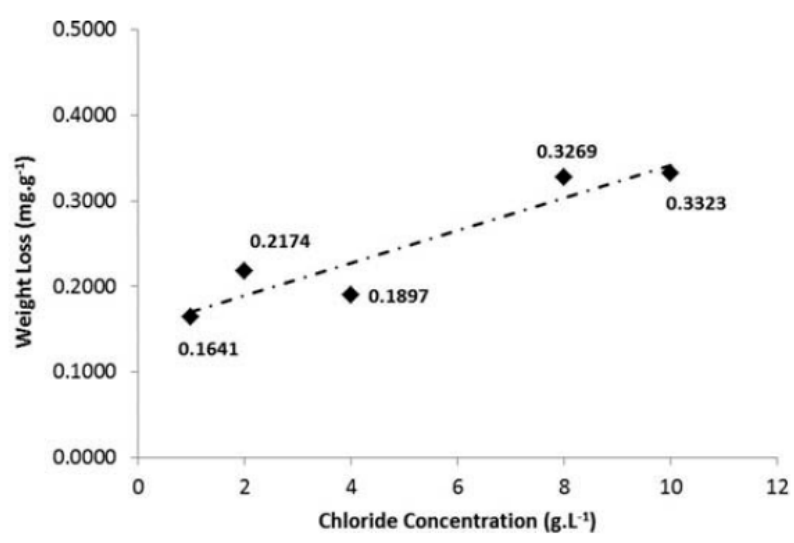

Figure 6. Aluminum weight loss in different chloride concentrations.

Figure 7 shows the potentiodynamic curves obtained to the effluent with no chloride additions and for the one with chloride concentration of 1 and $10 \mathrm{~g} \mathrm{~L}^{-1}$. When chloride is added to the effluent, it is possible to observe that pitting is the corrosion mechanism $(40,41)$, but the pitting corrosion is different in the two conditions. At a chloride concentration of $1 \mathrm{~g}$ $\mathrm{L}^{-1}$ the pitting potential is around $-0.6 \mathrm{~V}$ and at $10 \mathrm{~g} \mathrm{~L}^{-1}$ pitting corrosion appears at the open circuit potential, around $-0.8 \mathrm{~V}$, which is consistent to literature data $(31,42)$ that says that as chloride concentration increases, pitting potential decreases. In the absence of chloride ions, one can see that the aluminum oxide layer present on the metal surface does not present pitting corrosion regardless of the applied potential, which is in accor-dance with the results presented by Johnson et al. (43). By analyzing these data, one can observe that pitting corrosion occurs when chloride is present in the solution and can have significant contribution to the quantity of dissolved aluminum.

Table 4 also shows that the aluminum dissolution higher than expected was observed only with the smallest applied current density. When current density is increased, the influence of pitting corrosion should decrease because the electrochemically dissolved aluminum quantity is preponderant.

The comparison of current density effects for very different sodium chloride concentrations (1 and $\left.10 \mathrm{~g} \mathrm{~L}^{-1}\right)$ can be seen in Fig. 8(a). For lower current densities $\left(\mathrm{J}=0.047\left(\mathrm{~A} \mathrm{~cm}^{-2}\right)\right.$, the influence of chloride ions seems to be very significant, since in the presence of 10 times 
more $\mathrm{Cl}$ - ions, the COD value was practically reduced by half. Table 4 shows that the amount of dissolved aluminum at $10 \mathrm{~g} \mathrm{~L}^{-1}\left(0.3009 \mathrm{~g} \mathrm{~L}^{-1}\right)$ is higher than at $1 \mathrm{~g} \mathrm{~L}^{-1}\left(0.2617 \mathrm{~g} \mathrm{~L}^{-1}\right)$. This dissolved aluminum will be available to form precipitates that will act as coagulants and will end up reducing COD in the effluent. When current density is increased, the chloride concentration effect seems to disappear because more aluminum ions are available by electrochemical disso-lution in the anode and because such side effects as pitting corrosion may not play such an important role in the availability of aluminum ions to form precipitates.

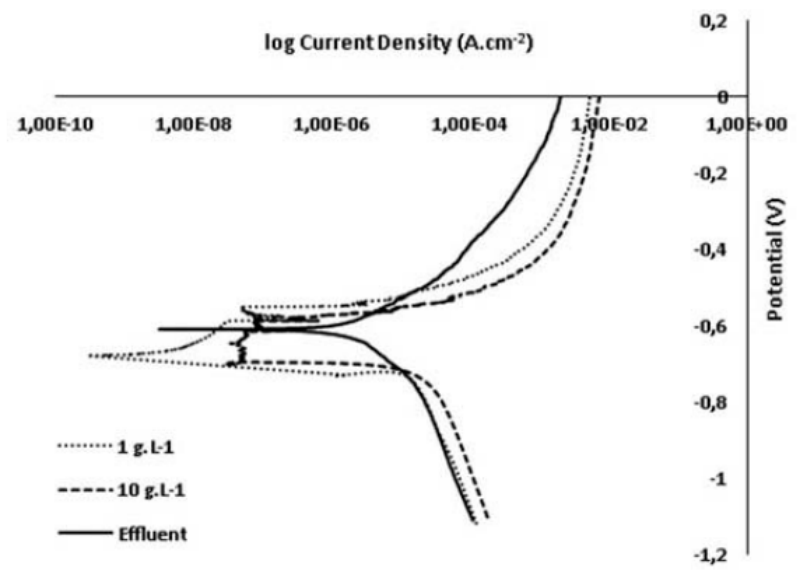

Figure 7. Potentiodynamic curves for the effluent without and with different chloride concentrations ( 1 and $10 \mathrm{~g} \mathrm{~L}^{-1}$ ).

The standard deviation between the obtained COD values for a given $\mathrm{Cl}$ concentration is minimal, as can be seen in Table 5.

Table 5. Standard deviation for COD values at $\mathrm{d}=20 \mathrm{~mm}$.

\begin{tabular}{lcc}
\hline COD Value $\left(\mathrm{g} . \mathrm{L}^{-1}\right)$ & Chloride Concentration $\left(\mathrm{g} . \mathrm{L}^{-1}\right)$ & Standard Deviation \\
\hline 23.329 & 1 & 0.017 \\
13.309 & 1 & 0.016 \\
12.977 & 1 & 0.008 \\
12.609 & 10 & 0.010 \\
12.756 & 10 & 0.036 \\
12.916 & 10 & 0.015 \\
\hline
\end{tabular}

Figure 8 (b) shows that the distance between the electrodes also plays an important role. When the electrodes are farther away from each other, current density effects in reducing COD are more visible. One can see that at $d=10 \mathrm{~mm}$ COD reduction was practically constant in the three applied current den- sities and at $d=20 \mathrm{~mm}$ the observed reduction was more than $50 \%$ higher when COD values obtained for the lower current density 
$-0.047 \mathrm{~A} \mathrm{~cm}^{-2}$ are compared with the two larger ones -0.094 and $0.188 \mathrm{~A} \mathrm{~cm}^{-2}$. The standard deviation for these COD values is also very low and can be seen in Table 6. Modirshahla et al. (16) and Sanchéz-Calvo et al. (27) have also observed that when the distance between the electro- des was increased, the COD reduction rate was reduced.
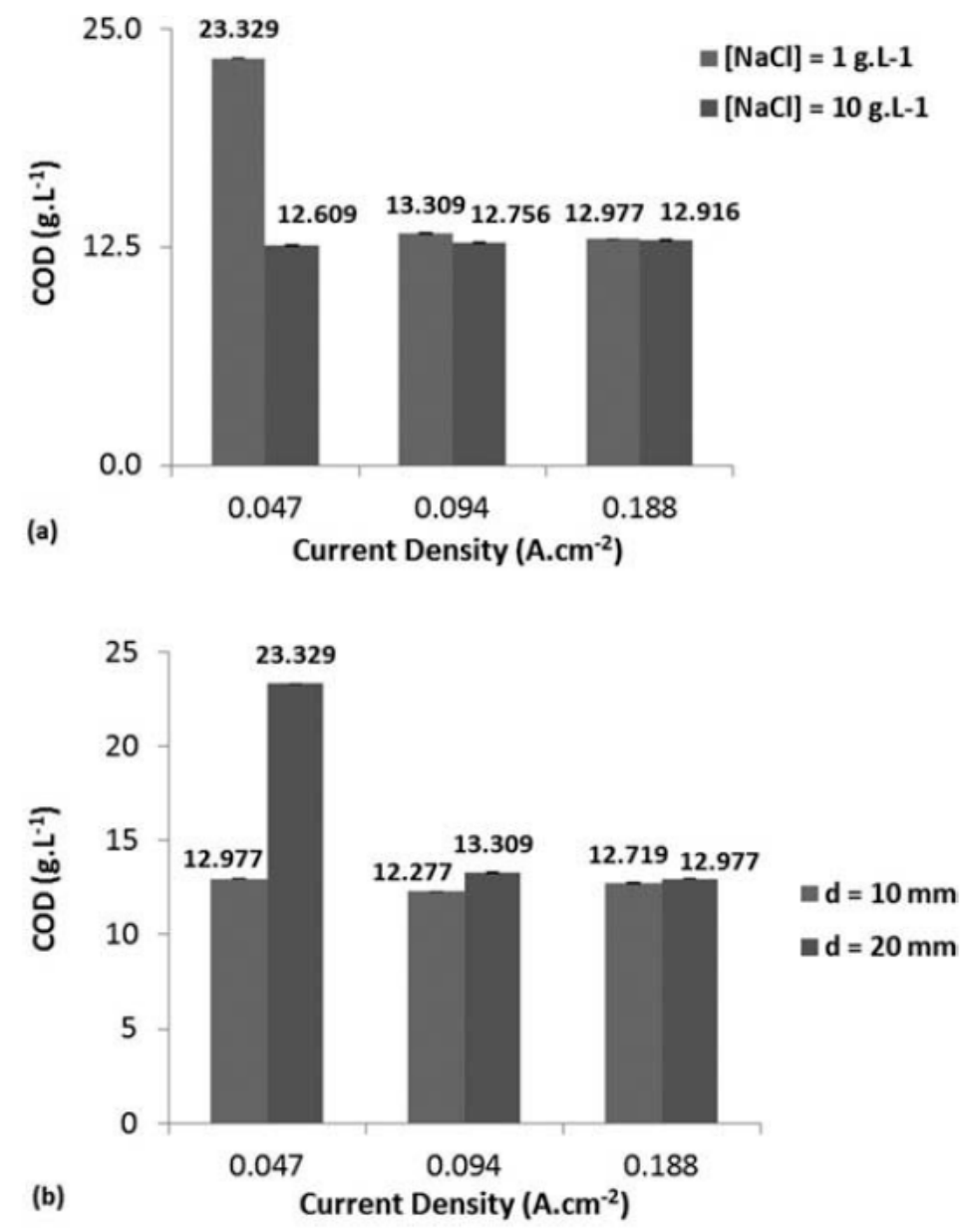

Figure 8. (a) Effect of current density over COD removal at $d=20 \mathrm{~mm}$. (b) Effect of current density over $\mathrm{COD}$ removal using $(\mathrm{NaCl})=1 \mathrm{~g} \mathrm{~L}^{-1}$ for different distances between electrodes $(\mathrm{d}=10$ and $20 \mathrm{~mm})$.

\section{Effect of the supporting electrolyte}

It is possible to observe in Fig. 9(a) that, for the three different electrode distances $(10,20$, and $40 \mathrm{~mm}$ ), the increase of $\mathrm{NaCl}$ concentration decreased the observed COD values until a minimum, after which point it starts to increase again. These lower COD removal rates as $\mathrm{Cl}^{-}$ concentration increases can indicate negative effects of their excessive presence as supporting 
electrolyte. Figure 9(b) shows the amount of dissolved aluminum at the anode and the results are in accordance with the literature, since higher quantities of dissolved aluminum resulted in higher COD removal rates.
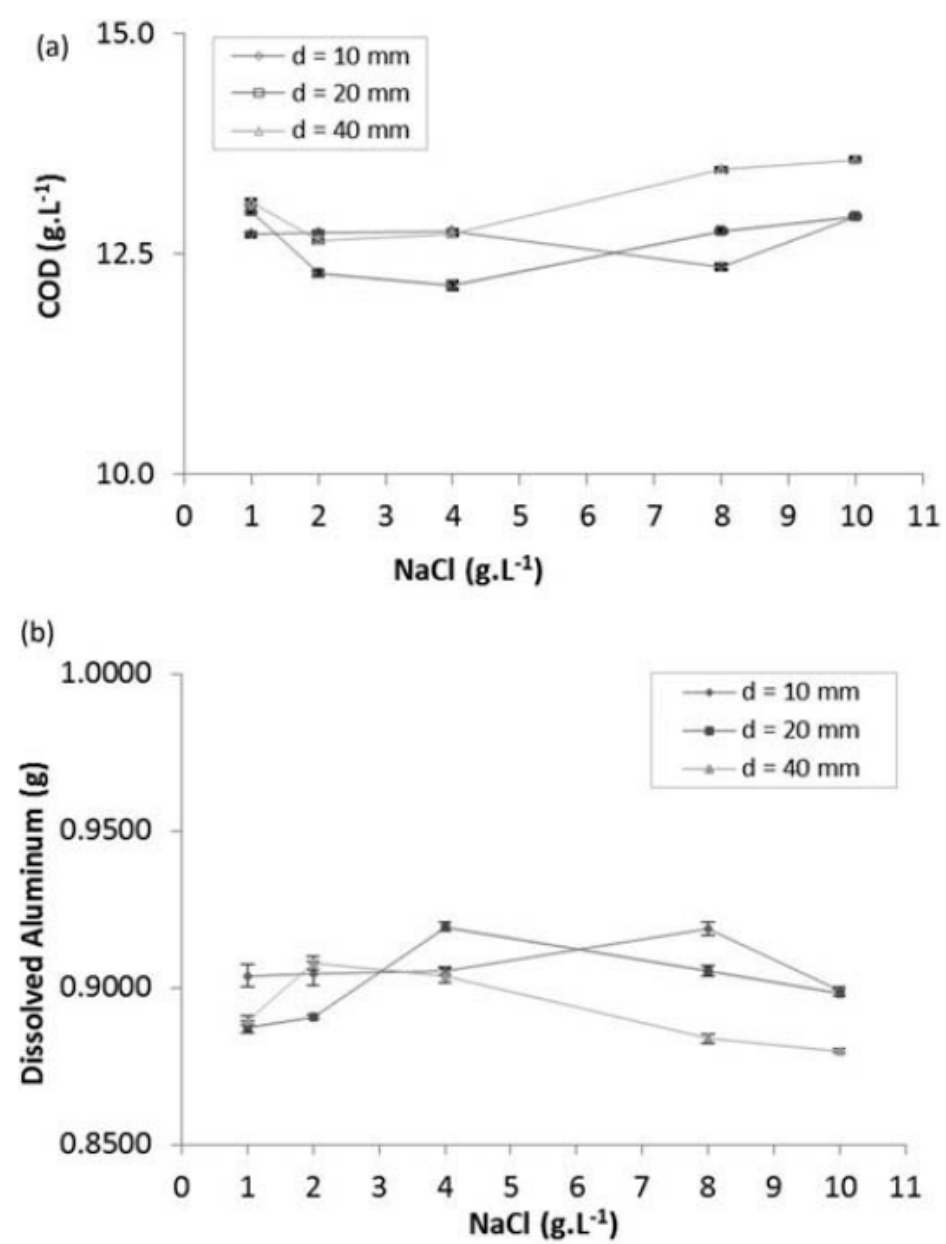

Figure 9. (a) The effect of the supporting electrolyte on COD removal at different electrode distances and $\mathrm{J}=0.188 \mathrm{~A} \mathrm{~cm}^{-2}$. (b) Dissolved aluminum at $\mathrm{J}=0.188 \mathrm{~A}$ $\mathrm{cm}^{-2}$ different chloride concentrations and electrode distances.

Figure 9(b) also shows that this highest quantity of dissolved aluminum is different for each electrode distance and it is shifted to a higher chloride concentration, as the distance is shorter. In fact, at $d=40 \mathrm{~mm}$ the highest quantity of dissolved aluminum is obtained at $2 \mathrm{~g} \mathrm{~L}^{-1} \mathrm{NaCl}$, at $\mathrm{d}=20 \mathrm{~mm}$ the highest value is at $4 \mathrm{~g} \mathrm{~L}^{-1}$ and at $\mathrm{d}=10 \mathrm{~mm}$ this condition is achieved at $8 \mathrm{~g} \mathrm{~L}^{-1}$.

In fact, when the distance increases, a lower efficiency of the removal parameters can be 
observed (Fig. 9b). The ohmic drop effects will be more significant, which means that there will be fewer interactions between the species. Besides, to maintain the same current density, the voltage of the system must be higher $(24,26,27)$. This is confirmed by the results in Fig. 10, where it is shown that when the electrode distance is larger, cell voltage is higher.

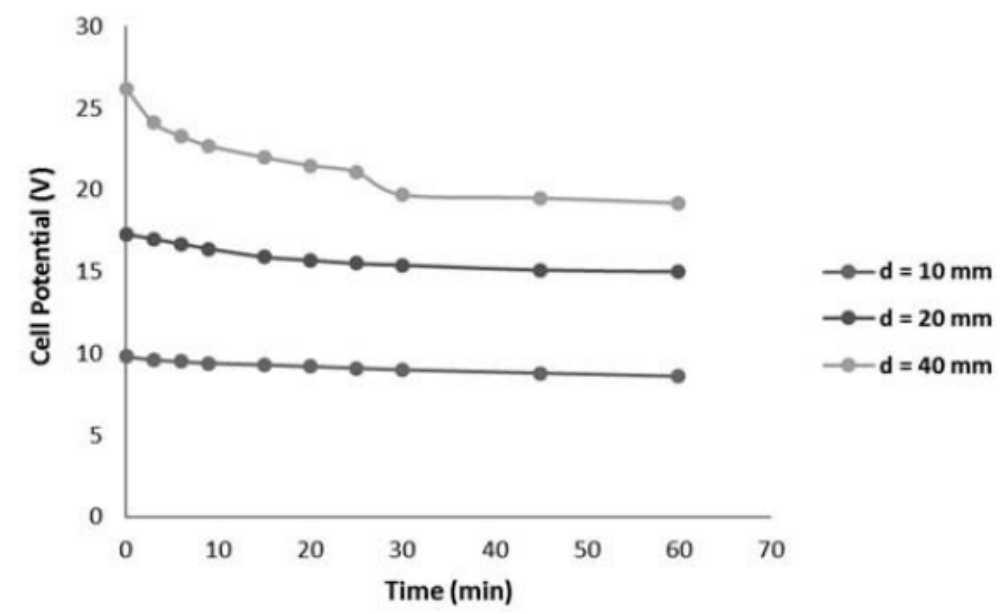

Figure 10. Variation of cell voltage with distance between the electrodes. $\mathrm{J}=0.047 \mathrm{~A} \mathrm{~cm}^{-2}$,

$$
(\mathrm{NaCl})=2 \mathrm{~g} \mathrm{~L}^{-1} \text { and } 2 \text { electrodes. }
$$

Figure 11(a) shows the differences in cell voltage with different chloride concentration. One can observe that as the chloride concentration is increased the initial voltage is lower; hence, the energy consumption of the process will also be lower. This is in accordance with the i m prove me nt in conductivity as chloride concentration is increased, shown in Fig. 11(b). It is also possible to see in all concentrations that cell voltage is getting lower as the reaction time goes by and reaches a pseudo-stationary state. The voltage decreased three times as the chloride concentration was increased from $1 \mathrm{~g} \mathrm{~L}^{-1}$ to $10 \mathrm{~g} \mathrm{~L}^{-1}$ and the curve shape is the similar for all chloride concentrations. In all tested chloride concentrations, the cell potential was significantly reduced during electrocoagulation/flotation, because of the dissolution of the sacrificial anode as aluminum hydroxide, which then prevents the formation of a passivation film.

Additionally, when the chloride content was increased, the initial cell potential reduced significantly, which can lead to a reduction in power consumption.

According to Fig. 12, all tested conditions removal rates were higher than $94 \%$. 

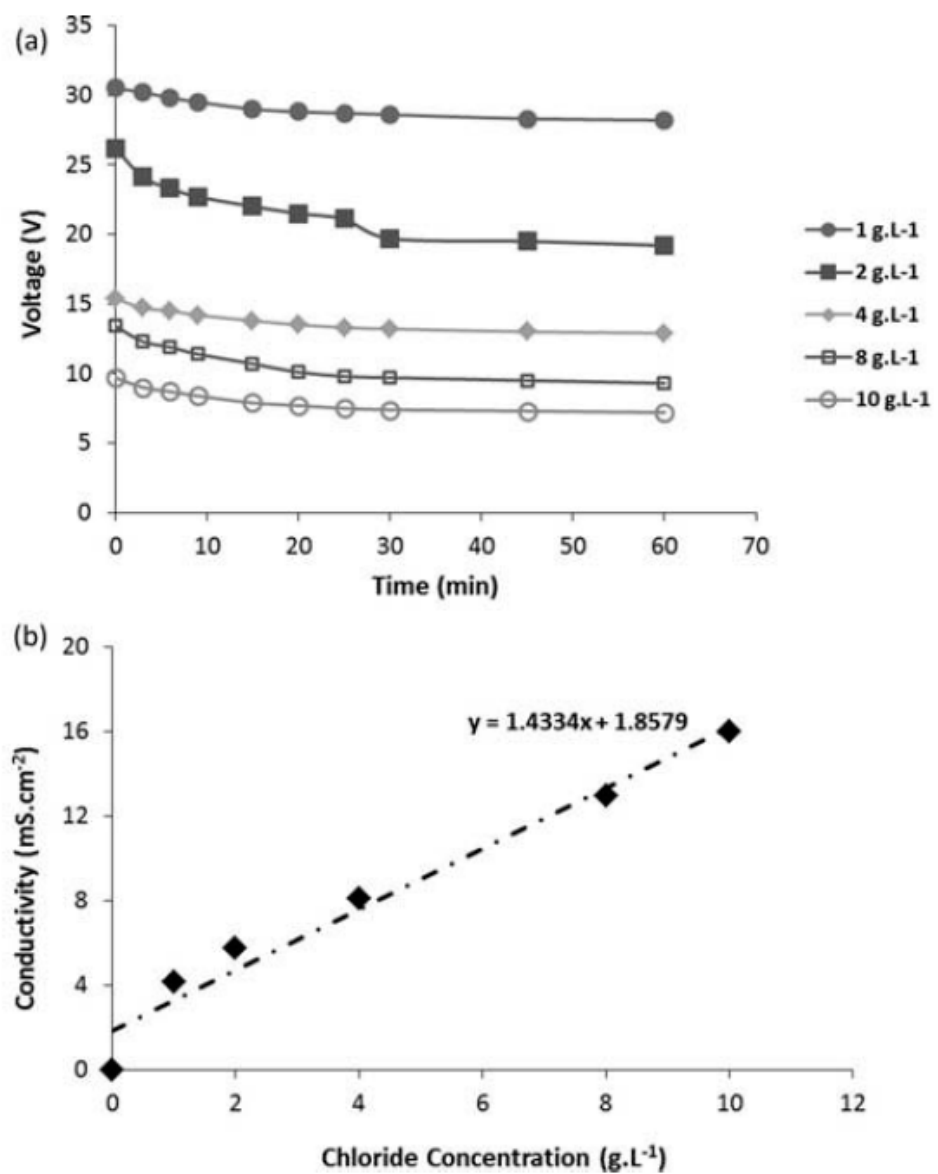

Figure 11. (a) Variation of cell voltage with time of electrocoa- gulation/electroflotation. $\mathrm{J}=$ $0.047 \mathrm{~A} \mathrm{~cm}^{-2}, \mathrm{~d}=10 \mathrm{~mm}$ and 2 electrodes. (b) Changes in conductivity with the increase of chloride concentration.

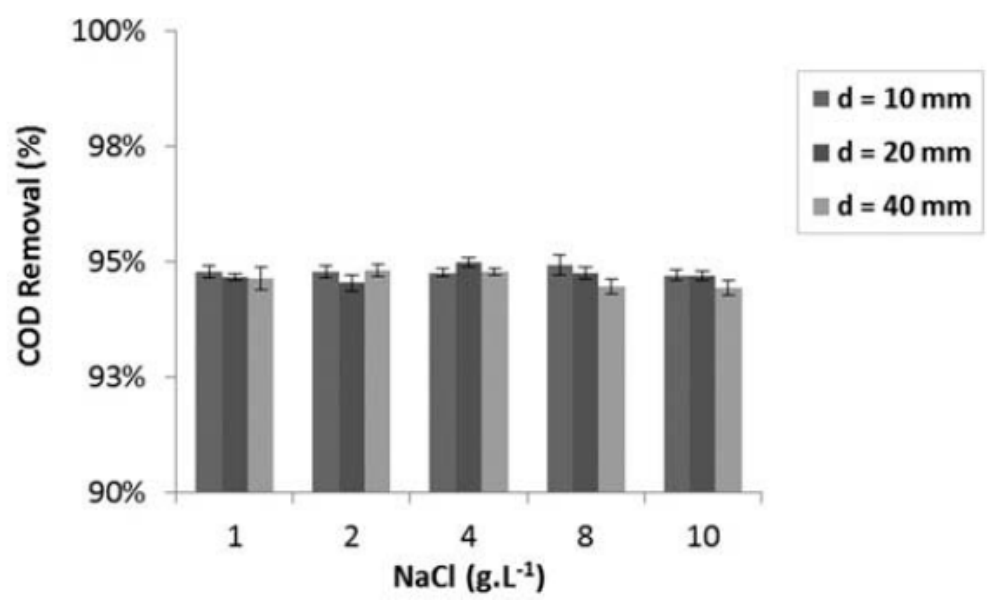

Figure 12. COD removal rates for $\mathrm{J}=0.188 \mathrm{~A} \cdot \mathrm{cm}^{-2}$, different $\mathrm{NaCl}$ concentrations and electrode distances. 


\section{Conclusions}

It was possible to use a technique, which is commonly used in aqueous effluents that have medium to high conductivity, on an effluent with low conductivity in order to break the emulsion, separate the graphite and significantly reduce COD. The chosen technique also uses fewer chemicals than the traditional physical-chemical treatments.

The results obtained in this work show that for all the tested conditions COD removal rates were higher than $94 \%$.

Operational parameters such as distance between electrodes, current density, and supporting electrolyte play important roles in the anodic dissolution of alu-minum. Due to this the parameters that would give the best results are $d=10 \mathrm{~mm}, \mathrm{~J}=0.188 \mathrm{~A} \mathrm{~cm}^{-2}$, and $\mathrm{NaCl}$ concentration of $8 \mathrm{~g} \mathrm{~L}^{-1}$.

\section{Funding}

GKN Driveline Brazil is gratefully acknowledged for all the financial support and material given to the execution of this paper. Also, Capes, FAPERGS, CNPq, and Cyted are thanked for their financial support. 


\section{References}

[1] Rodriguez, J., Stopic, S., Krause, G., Friedrich, B. (2007) Feasibility assessment of electrocoagulation towards a new sustainable wastewater treatment. Env Sci Pollut Res. DOI: http://dx.doi.org/10.1065/espr2007.05.424.

[2] Rajeshwar, K.; Ibañez, J. (1997) Environmental Electrochemistry: Fundamentals and Applications in Pollution Abatement; Academic Press: San Diego, CA.

[3] Cañizares, P., Jimenez, C., Martínez, F., Saéz, C., Rodrigo, M. A. (2007) Study of the electrocoagulation process using aluminum and iron electrodes. Industrial and Engineering ChemistryResearch,46(19):6189-6195.

[4] Cañizares, P., Martínez, F., Lobato, J., Rodrigo, M. A. (2007) Break-up of oil in water emulsions by electrochemical techniques. Journal of Hazardous Materials, 145(1-2): 233240.

[5] Cañizares, P., Martínez, F., Jimenez, C., Lobato, J., Rodrigo, M. A. (2007) Coagulation and electrocoagula- tion of wastes polluted with colloids. Separation Science and Technology, 42(10): 2157-2175.

[6] Cañizares, P., Martínez, F., Jimenez, C., Saez, C., Rodrigo, M. A. (2008) Coagulation and electrocoagula- tion of oil-in-water emulsions. Journal of Hazardous Materials, 151(1): 44-51.

[7] Holt, P. K.; Barton, G. W.; Mitchell, C. A. (2005) The future for electrocoagulation as a localized water treat- ment technology. ChemospHere, 59(3): 355-367.

[8] Katal, R.; Pahlavanzadeh, H. (2011) Influence of different combinations of aluminum and iron electrode on elec- trocoagulation efficiency: Application to the treatment of paper mill wastewater. Desalination, 265(1-3): 199-205.

[9] Chen, G. (2004) Electrochemical technologies in waste- water treatment. Separation and Purification Technology, 38(1): p. 11-41. 
[10] Aber, S.; Amani-Ghadim, A. R.; Mirzajani, V. (2009) Removal of $\mathrm{Cr}(\mathrm{VI})$ from polluted solutions by electro- coagulation: Modeling of experimental results using artificial neural network. Journal of Hazardous Materials, 171(1-3): 484-490.

[11] Arroyo, M. G., Pérez-Herranz, V., Montañes, M. T., García-Antón, J., Guiñón, J. L. (2009) Effect of $\mathrm{pH}$ and chloride concentration on the removal of hexavalent chromium in a batch electrocoagulation reac- tor. Journal of Hazardous Materials, 169(1-3): 1127-1133.

[12] Bande, R. M., Prasad, B., Mishra, I. M., Wasevar, K. L. (2008) Oil field effluent water treatment for safe disposal by electroflotation. Chemical Engineering Journal, 137(3): 503509.

[13] Bensadok, K.; El Hanafi, N.; Lapicque, F. (2011) Electrochemical treatment of dairy effluent using combined $\mathrm{Al}$ and Ti/Pt electrodes system. Desalination, 280(1-3):244-251.

[14] Ben Mansour, L.; Chalbi, S. (2006) Removal of oil from oil/water emulsions using electroflotation process. Journal of Applied Electrochemistry, 36(5): 577-581.

[15] Kobya, M.; Can, O. T.; Bayramoglu, M. (2003) Treatment of textile wastewaters by electrocoagulation using iron and aluminum electrodes. Journal of Hazardous Materials, 100(13): 163-178.

[16] Modirshahla, N.; Behnajady, M. A.; Kooshaiian, S. (2007) Investigation of the effect of different electrode connections on the removal efficiency of Tartrazine from aqueous solutions by electrocoagulation. Dyes and Pigments, 74(2): 249-257.

[17] Daneshvar, N.; Khataee, A. R.; Amanighadim, A. R; Rasoulifard, H. (2007) Decolorization of C.I. Acid Yellow 23 solution by electrocoagulation process: Investigation of operational parameters and evaluation of specific electrical energy consumption (SEEC). Journal of Hazardous Materials Volume, 148(3): 566-572.

[18] Heidman, I., Calmano, W. (2008) Removal of $\mathrm{Zn}(\mathrm{II}), \mathrm{Cu}(\mathrm{II}), \mathrm{Ni}(\mathrm{II}), \mathrm{Ag}(\mathrm{I})$ and $\mathrm{Cr}(\mathrm{VI})$ present in aqueous solutions by aluminium electrocoagulation. Journal of Hazardous Materials, 152(3): 934-941. 
[19] Heidman, I., Calmano, W. (2008) Removal of $\mathrm{Cr}(\mathrm{VI})$ from model wastewaters by electrocoagulation with Fe electrodes. Separation and Purification Technology, 61(1): 15-21.

[20] Yildiz, Y.; Koparal, A. S.; Keskinler, B. (2008) Effect of initial pH and supporting electrolyte on the treatment of water containing high concentration of humic substances by electrocoagulation. Chemical Engineering Journal, 138(1): 63-72.

[21] Trompette, J. L.; Vergnes, H. (2009) On the crucial influence of some supporting electrolytes during electrocoagulation in the presence of aluminum electrodes. Journal of Hazardous Materials, 163(2-3): 1282-1288.

[22] Mouedhen, G.; Feki, M.; De Petris-Wery, M. ; Ayedi, H. F. (2009) Electrochemical removal of $\mathrm{Cr}(\mathrm{VI})$ from aqueous media using iron and aluminum as electrode materials: Towards a better understanding of the involved phenom- ena. Journal of Hazardous Materials, 168(2-3): 983-991.

[23] Arslan-Alaton, I.; Kabdasli, I.; Sahin, Y. (2008) Effect of operating parameters on the electrocoagulation of simulated acid dyebath effluent. The Open and Environmental \& Biological Monitoring, 1: 1-7.

[24] Daneshvar, N.; Ashassi-Sorkhabi, H.; Tizpar, A. (2003) Decolorization of orange II by electrocoagulation method. Separation and Purification Technology, 31(2): 153-162.

[25] Gao, S.; Maoan Du, Jiayu Tian, Jianyu Yang, Jixian Yang, Fang Ma, Jun Nan (2010) Effects of chloride ions on electro-coagulation-flotation process with aluminum electrodes for algae removal. Journal of Hazardous Materials, 182(1-3): 827-834.

[26] Nasrullhah, M.; Singh, L.; Wahid, Z. (2012) Treatment of sewage by electrocoagulation and the effect of high current density. Energy and Environmental Engineering Journal, 1(1): 27-31.

[27] Sanchez-Calvo, L., Leclerc, J. P., Tanguy, G., Cames, M. C., Paternotte, G., Valentin, G., Rostan, A., Lapicque, F. (2003) An electrocoagulation unit for the purification of soluble oil wastes of high COD. Environmental Progress, 22(1): 57-65. 
[28] Bensadok, K., Benammar, S., Lapicque, F., Nezzal, G. (2008) Electrocoagulation of cutting oil emulsions using aluminium plate electrodes. Journal of Hazardous Materials, 152(1): 423430.

[29] Jimenez Izquierdo, C., Cañizares, P., Rodrigo, M. A., Leclerc, J. P., Valentin, G., Lapicque, F. (2010) Effect of the nature of the supporting electrolyte on the treatment of soluble oils by electrocoagulation. Desalination, 255(1-3): 15-20.

[30] Gonzales, L. G. V., Torem, M. L. (2010) O efeito de dois diferentes anodos metálicos na eletrocoagulação de efluentes oleosos sintéticos. Estudos Tecnológicos, 6 (2):57-67.

[31] Mouedhen, G., Feki, M., De Petris Wery, M., Ayedi, H.F. (2008) Behavior of aluminum electrodes in electro- coagulation process. Journal of Hazardous Materials, 150(1): 124-135.

[32] Mechelhoff, M., Kelsall, G. H., Graham, N. J. D. (2013) Super-faradaic charge yields for aluminium dissolution in neutral aqueous solutions. Chemical Engineering Science, 95(5):353359.

[33] Mechelhoff, M., Kelsall, G. H., Graham, N. J. D. (2013) Electrochemical behavior of aluminum in electrocoa- gulation processes. Chemical Engineering Science. 95 (5): 301-312.

[34] Natishan, P. M., O'grady, W. E. (2014) Chloride ion interactions with oxide-covered aluminum leading to pitting corrosion: A review. Journal of the Electrochemical Society, 161(9): C421-C432.

[35] Jafarzadeh, K., Shahrabi, T., Hadavi, S. M. M., Hosseini, M. G. (2007) Role of chloride ion and dis-solved oxygen in electrochemical corrosion of aa5083- h321 aluminum-magnesium alloy in $\mathrm{NaCl}$ solutions under flow conditions. J. Mater. Sci. Technol., 23(5): 623-628.

[36] Afzal, S. N., Ali Shaikh, M. A., Mustafa, Nabi, C. M., Ehsan, M., M. Q., Khan, A. H. (2007) Study of alumi- num corrosion in chloride and nitrate media and its inhibition by nitrite. Journal of Nepal Chemical Society, 22:26-33. 
[37] Despić, A. R., Atanasoska, Lj, D., Dražic, D. M. (1983) Impedance of aluminum in chloride solutions during anodic dissolution at high current densities. Electrochimica Acta, Volume 28(3): 397-401.

[38] Pyun, S. I., Moon, S. M., Ahn, S. H., Kim, S. S. (1999) Effects of $\mathrm{Cl}^{-}, \mathrm{NO}_{3}{ }^{-}$and $\mathrm{SO}_{4}{ }^{-}$ions on anodic dissolution of pure aluminum in alkaline solution. Corrosion Science, 41:653-667.

[39] Lee, W. J., Pyun, S. I. (1999) Effects of hydroxide ion addition on anodic dissolution of pure aluminum in chloride ion-containing solution. Electrochimica Acta, 44: 4041-4049.

[40] Dražić, D. M., Popić, J. P. (1999) Corrosion rates and negative difference effects for Al and some alloys. Journal of Applied Electrochemistry, (29): 43-50.

[41] Tomcsányi, L., Varga, K., Bartik, I., Horányi, H., Maleczki, E. (1989) Electrochemical study of the pitting corrosion of aluminum and its alloys. II. Study of the interaction of chloride ions with a passive film on aluminum and initiation of pitting corrosion. Electrochimica Acta, 34: 855-859.

[42] Szklarska-Smialowska, Z. (1999) Pitting Corrosion of Metals, NACE, Houston, TX.

[43] Johnson, C. M., Wall, F. D., Barbour, J. C., Martinez, M. A. A study of localized corrosion in $\mathrm{Al}$ resulting from the controlled introduction of $\mathrm{Cl}$, Materials Research Society Spring Symposium Proceedings, MRS Proceedings, Volume 781 - 2003, MRS Spring Meeting Symposium Z - Mechanisms in Electrochemical Deposition and Corrosion, Editors: J.C. Barbour, R. M. Penner, P. C. Searson. 